\title{
Dispersal Syndromes of fossil Seeds from the Lower Permian of Paraná Basin, Rio Grande do Sul, Brazil
}

\author{
JULIANE M. SOUZA and ROBERTO IANNUZZI \\ Depto de Paleontologia e Estratigrafia, Instituto de Geociências, Universidade Federal do Rio Grande do Sul, \\ Av. Bento Gonçalves, 9500, 91509-900 Porto Alegre, RS, Brasil.
}

Manuscript received on March 17, 2010; accepted for publication on November 14, 2010.

\begin{abstract}
The morphological analysis of seeds has been an important subject in modern ecological studies, once it provides evidence about the biology and adaptations of the parent plant. However, this kind of study has been restricted to the ecology of modern plants and is rarely used in interpretations of Paleozoic data. From the understanding of dispersal syndromes analysis as an important tool to paleoecological reconstruction, this study provides a first approach using this tool with seeds from the Lower Permian strata of southern Paraná Basin in Rio Grande do Sul. Based on previously classified seeds and using their biological and taphonomic data, the syndrome of dispersal was interpreted, and their placement in successional groups (pioneer, early-successional and later-successional) was suggested. Seven morphospecies were analyzed: Samaropsis gigas, representing a later-successional species living in water bodies with hydrochory as its dispersal syndrome; Samaropsis kurtzii, typical of early-successional species showing anemochory as its dispersal syndrome and living in distal areas in relation to water bodies; Samaropsis aff. S. millaniana, Cordaicarpus aff. C. brasilianus, Cordaicarpus cerronegrensis and Cordaicarpus truncata have typical characteristics of pioneer plants, exhibiting barochory as their primary dispersal syndrome with other syndromes associated.
\end{abstract}

Key words: Samaropsis, Cordaicarpus, dispersal syndromes, ecological groups, Lower Permian, Paraná Basin.

\section{INTRODUCTION}

Frequent studies about contemporaneous floras have shown that the seed dispersal process causes significant effects on the vegetation composition. According to Tiffney (2004), the dispersal influences the composition of the general structure of plant communities.

This influence is due to the fundamental role of the dispersal process linking the reproductive cycle of adult plants with the establishment of their

Correspondence to: Juliane Marques de Souza

E-mail: juliane.marques.souza@gmail.com offspring, that is to say, in the inter-generational relationship. According to Wang and Smith (2002 p.379), "seed dispersal dynamics presumably influences plant processes ranging from the colonization of new habitats to the maintenance of diversity, with implications for succession, regeneration and conservation".

Some authors (Howe and Smallwood 1982, Hughes et al. 1994, Willson and Traveset 2000, Tiffney 2004) enumerate the main ecological functions of the dispersal, as follows: i) to help to escape from excessive mortality of seeds and 
seedlings caused by the competition and predation near the parent plant, ii) to colonize suitable sites for establishment, and iii) to allow the movement of seeds to specific microsites that are appropriated to the ecology of the parent plant.

Hence, in order to obtain success on the offspring establishment, plants adopt different dispersal strategies, which may be sometimes seen in the diaspore morphology (Harper et al. 1970). According to Hughes et al. (1994 p.933), "the diaspores of many plant species have particular morphological structures that enhance their probability of being dispersed away from the mother-plant".

In this case the diaspore is the reproductive unit of the parent plant, which is dispersed and may be both the fruit and seed (Van der Pjil 1969, Howe and Smallwood 1982, Tiffney 1984, Willson and Traveset 2000).

The differentiated structures such as plumes, wings, cork, viscous material, hooks and colored seed coat are thus, an important tool to reveal the dispersal strategies adopted by the species (Harper et al. 1970, Howe and Smallwood 1982). Furthermore, the size and the quantity of diaspores reveal much about the ecology of the parent plant, giving information about its habit and habitat (Tiffney 1984).

The studies about seed dispersal are common in the Ecology of modern plants; however, in Paleontology they still are incipient. The scarcity of records and the limitation of the analysis using taphonomic data (sometimes bi-dimensional and without anatomic structures preserved) make this subject sometimes uninteresting. Regarding this, Tiffney (2004 p.2) pondered that "paleontological evidences provide only a snapshot in time generally based on the morphology of one organ or organism", and illustrated it saying that it is rare to found a fossil animal with a intestine full of identifiable fruits or seeds.

However, despite the difficulties that are inherent in the science of Paleontology, some studies were published mainly about the paleozoic and mesozoic flora of Euramerica (Tiffney 1984, 1986, 2004, Eriksson et al. 2000). These studies, in turn, give information about the predominant dispersal strategies of the tropical flora that were typical of that region in those eras.

Regarding the gondwanic flora, Archangelsky (1995) discussed the biological meaning of the morphology of a new species of seed from the Lower Permian of Argentina that was described in the same study. The author refers, at the end, the probable strategy of dispersal of the described seed. Tiffney (1986) contributed with this kind of study by presenting a summary containing which was done about this subject until then.

From the taxonomic analysis performed with seeds from the Lower Permian of the Paraná Basin, it was noticed that these structures could be used as tools to the paleoecologic analysis due to the amount and quality of the material available. This analysis would complement studies made from other plants remains (e.g. leaves).

Once the morphological features of seeds reveal much about the reproductive strategies of the plants, they become a useful tool to the paleoecological and paleoenvironmental reconstruction. Furthermore, this analysis may help to define the ecological group of the plants (i.e. pioneer, early-successional or later-successional) (Gandolfi et al. 1995). According to Tiffney (1984), the seeds offer an excellent start point for paleobiological researches based on modern ecological studies.

For this tool usage, it is important to analyze the information about the probable dispersal syndrome adopted, the size of seeds and their quantity. However, in the case of the fossil material, the analysis must contemplate the taphonomic features of the records as, for instance, transport degree, depositional environment and preservational condition of the material. This information aims to enrich the data.

Therefore, the present study aims to identify the probable dispersal syndrome of the main seeds 
recovered from the Lower Permian deposits of Rio Grande do Sul State, Brazil, facing the morphology and depositional context presented by seeds. Hence, it intends to contribute with the paleoecological and paleoenvironmental reconstructions that have been done concerning the Paleozoic flora of the southern Paraná Basin.

\section{MATERIALS AND METHODS}

The material studied was recovered from different outcrops distributed around the municipality of Mariana Pimentel, Rio Grande do Sul State (RS), and it is housed at the Departamento de Paleontologia e Estratigrafia (DPE), Instituto de Geociências (IG), Universidade Federal do Rio Grande do Sul (UFRGS). The seeds are preserved as impressions and compressions forms, and are identified under de MP-Pb code. (Figure 1)

The analysis of seeds dispersals followed some criteria widely diffused on modern Ecology. So, to the present study used as analysis criteria: i) seed size; ii) presence or absence of dispersal structures and their association with dispersal syndromes; and iii) the relation between dispersal syndrome and seed size. These criteria were understood as part of the "Biological features" presented by the structures analyzed.

The interpretation of the "Taphonomic features" was also understood as necessary, considering that it is fossil material. This analysis used as evaluation criteria: i) the preservational condition of the material; ii) the kind of depositional site where the fossil was recovered; and iii) the transport degree. These criteria were discussed hereafter.

Biological FeATURES

Biological features refer to the whole information that can be obtained by the morphological analysis without the interference of the process of fossilization suffered by the structure. Each feature mentioned will be discussed hereafter.

\section{Seed size:}

Seeds are composed by the embryo plus the nutritive reserve, as well as by a protective testa. This nutritive reserve is responsible for the nutrition of the embryo in the first stage of its life, from germination until the seedling establishment. Seeds with more nutritive reserves give more autonomy to the seedlings until they become self-supporting (Harper et al. 1970, Leishman et al. 2000).

In this context, following some authors as Harper et al. (1970), Coomes and Grubb (2003) and Tiffney (1986, 2004), small seeds are supposedly associated with pioneer plants that live in light-rich environments because the seedlings are provided with enough nutritive reserve to become quickly self-supporting.

On the other hand, large seeds have a great amount of nutritive reserve, which allows the seedling to establish a large leaf area before it becomes self-supporting. Then, large-seeded plants are typical of closed, poor-light environments, and may be related to an adaptation to the high amount of litter in the establishment site (Harper et al. 1970, Tiffney 1984).

In addition, large-seeded plants have more success in the establishment of the offspring, being favored in environments with high competition, shadow or water and mineral deficiency (Harper et al. 1970, Jakobsson and Eriksson 2000).

In contrast, plants with intermediate size are often in the intermediate zone of succession (Tiffney 1986), maximizing the number of sites to their establishment and hence increasing their competitiveness (Jakobsson and Eriksson 2000).

About the energy dispensed, according to Moles et al. (2005, p. 576), "small-seeded plants are more able to produce seeds for a given amount of energy than large-seeded species"; thus, small- 


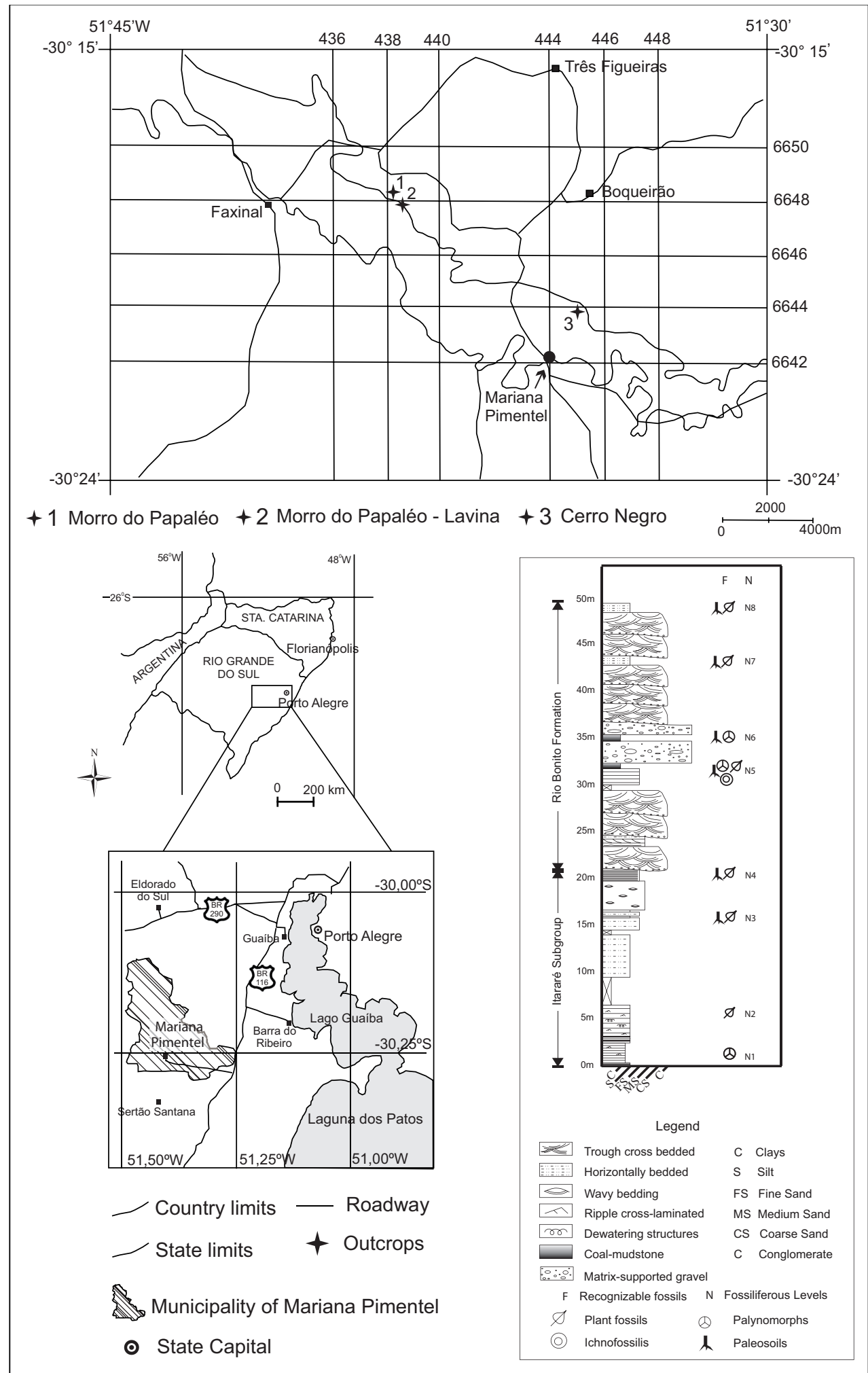

Figure 1: Map of the Mariana Pimentel Municipality in eastern Rio Grande do Sul with the location of the outcrops: 1, Morro do Papaléo; 2, Faxinal Section; 3, Cerro Negro (mod. from Paim et al. 1983, Iannuzzi et al. 2006 and Souza and Iannuzzi 2009). Stratigrafic section of the Morro do Papaléo outcrop showing the plant-bearing levels as described in the text (mod. from Iannuzzi et al. 2007, Souza and Iannuzzi 2009). 
seeded species compensate the deficit in the offspring establishment producing seeds in large scale (Jakobsson and Eriksson 2000, Leishman et al. 2000). On the other hand, the characteristic small-scale production of large-seeded plants leads to an increase in the selection by improving the dispersion of individuals, i.e., investing in dispersal attributes (Eriksson et al. 2000).

In short, the analysis of seed size and its abundance in the records can bring information about the probable ecological group of the parent plant and the spatial distribution of fossil species.

It should also be noted that, facing the dynamics of nature, the trends mentioned herein can find variations, which must be considered carefully when dealing with paleontological records. Therefore, it is important to work with qualified, well-preserved and abundant material.

Presence or absence of dispersal structures and their association with dispersal syndromes:

According to Tiffney (1986), the morphological characteristics of diaspores can be broadly associated with particular dispersal modes or agents. The dispersal can be achieved in two basic ways - abiotic or biotic (Tiffney 1986, 2004). The abiotic is a kind of dispersal achieved by nonliving agents as water and wind. The biotic involves animals as fishes, insects, birds, etc.

Van der Pjil (1969) has organized and summarized what he called "dispersal syndromes" based on the two basic ways of dispersal mentioned and their relation with different agents and dispersal structures. The most important syndromes described as abiotic were: i) Anemochory: by wind dispersal; diaspores may be extraordinarily small and possess wings or plumes; ii) Hydrochory: by water dispersal without a specific morphology or with special tissues that allow flotation; and iii) Authocory: by the dispersal of the plant itself, usually related with the fructification. Among the biotic ways, Van der Pjil established: iv) Epizoochory: by the transportation of diaspores on the outer surface of animals achieved by hooks or sticky substance; v) Fish dispersal: the dispersal is made by fishes and the diaspores do not have a specific morphology; vi) Saurochory: by reptile dispersal and with colorful diaspores; vii) Ornithochory: by bird dispersal and usually involves colorful diaspores, without smell; viii) Mammal dispersal: the dispersal is made by mammals, with diaspores morphologically diverse; and ix) Barochory: the absence of dispersal syndrome, with the dispersal being achieved by the gravity.

These syndromes are sometimes associated. The diaspores may have more than one dispersal structure or more than one kind of dispersal agent (Tiffney 2004).

Furthermore, it is important to emphasize that some important morphological characteristics are not preserved in the fossil record as, for instance, colors, smell and sticky substance.

At the same time, the morphology of abioticallydispersed diaspores is easier to recognize at the fossil record than that related to biotic dispersal (Tiffney 1986). In other words, the presence of wings, plumes of hairs or floating tissues are indicators of the interaction of nonliving agents in the dispersal process. However, it is important to analyze the efficiency of these structures in relation to the seed size to make sure about these interpretations.

\section{Relation among dispersal syndrome and seed size:}

Besides the presence of differentiated structures adapted to the dispersion, the seed size may give some information about the dispersal strategies adopted by the species. Regarding it, Hughes et al. (1994) state that the seed size can generate limitations about the dispersal mode adopted, as in the ants case, for instance, in which these insects are probable unable to transport seeds bigger than 
$100 \mathrm{mg}$. However, the authors concluded, after studies with temperate flora, that these limitations are usually related to large seeds groups.

According to Tiffney (1986) and Lorts et al. (2008), a few large diaspores move abiotically. Among these, the most common dispersal syndrome is the hydrochory, once large diaspores have difficult in moving abiotically without a welldeveloped dispersal structure. Thus, the majority is often biotically-dispersed.

Furthermore, seeds smaller than $0.1 \mathrm{~g}$ do not have specific dispersal structures, and it is because this kind of seed is effectively moved by wind even without these structures (Hughes et al. 1994).

Regarding the fossil record, Chaloner and Sheerin (1981) published a study that established the three main dispersal strategies present in the Devonian and Carboniferous seeds. Such study was based on seeds architectures. To the authors, seeds with a diameter until $5 \mathrm{~mm}$ would be able to be wind-dispersed; those until $10 \mathrm{~mm}$ would have some dispersal structures as wings or plumes; and those until 100mm would have an inner testa (sclerotesta) and other outer fleshy (sarcotesta) that would allow the biotic dispersal or the dispersal by water.

In this context, it was concluded that not only the dispersal structure must be analyzed to understand the reproductive strategies of the plants, but also the size of the diaspores, which have a relevant role on dispersal processes and assume important ecological functionalities.

\section{TAPHONOMIC FEATURES}

These features probably make the studies with fossils quite different from those performed with the modern flora because these features can change significantly the morphology of the structures. In these situations, two specimens of a same species may be seem completely different.

It is intended, in the following three items, to identify and analyze the possible interferences that the taphonomic process may have impressed on the record in order to obtain more accurate information and minimize taphonomic trends.

The taphoflora analysis, in turn, relates the record of fossils remains to the depositional site; in other words, it shows "the sedimentological context in which the preserved fossil assemblage occurred" (Gastaldo et al. 1995 p.341). This analysis is important to obtain information about the taphonomic history of the fossil, the flora assemblage and the depositional site that allow the paleoenvironmental reconstructions. The taphonomic features are discussed hereafter.

\section{The preservational condition of the material}

A well-preserved material gives reliability to the study. Thereby, three factors must be considered to analyze this material: the chemical resistance of the structure, the transportation effects (break and abrasion) and post-burial changes. These factors are related to the decay process that changes according to the nature of the structure, of the species and of the environment to which it is exposed (Spicer 1991). These organisms with tissues of thick resistance are, thus, preferentially preserved (Scott and Collinson 1983).

Chemical resistance is related to the main substance that composes the structure; in the case of seeds, cellulose and lignin. The thickness of these tissues changes according to the species. Tree trunks, seeds and pollen are usually fairly durable and can be reworked before final deposition. On the other hand, leaves tend to decay rapidly (Martin 1999).

Hence, the transportation effect depends on the resistance of the structure (Scott and Collinson 1983), the flotation capability and the decay state of the structure in the beginning of the transportation. Structures with morphologies adapted to float or with a hydrodynamic shape can be transported for longer distances without suffering many damages (Spicer 1991). Furthermore, decaying structures tend to suffer more damage derived from transportation. 
Finally, burial and fossil diagenesis submit the plants remains to different physical and chemical processes (for instance, compression of the sediment, and diagenetic mineralization), which can change completely the morphology of the material (Bateman 1991).

To sum up, the speed and severity of degradation, compression and mineralization determine the potential and the form of the plant preserved (Bateman 1991). Therefore, taxonomical, paleoenvironmental and paleoecological analysis must be related to taphonomic interpretations in order to get reliable results and differentiate the morphological features from those resulted from processes of preservation.

\section{Deposicional site:}

The place where the deposition, the burial and the fossil diagenesis occur is known as depositional site or depositional environment. The analysis of this record gives important information about the depositional system, such as the system energy, the presence or absence of oxygen, and the flow and direction of stream (Holz and Simões 2002).

The presence of sedimentary structures of unidirectional flow can infer the presence of the stream and, consequently, a system with energy. If this system had flown so, the fossils remains found there probably suffered some effects from the action of this current and therefore may have been transported (Holz and Simões 2002).

In this context, the process reported in the depositional site may occur with the fossil preserved in this site (Holz and Simões 2002). After this data analysis, it is possible to enrich the information with the morphology of fossils remains and, thus, enhance the comprehension of the context.

\section{Transport degree:}

Finally, the third point of analysis refers to the proximity of the fossil assemblage in relation to their living environment and, in the seeds case, in relation to the parent plant. This information is essential for any paleoecological study, since lower is the transportation suffered by the remains, larger is the information about their living environment.

To define if plant remains are preserved near or far from their origin, the following terms are used: autochthony, parautochthony and allochthony. In this study, it was accepted the definition of Bateman (1991) of autochthony as remains preserved in situ (position of life), parautochthony as the record of disarticulated plant-parts preserved within their community of origin, and allochthony as plantparts transported beyond their community of origin and living environment.

Considering that this transportation carries the structures away from their original living place, the analysis of the allochthonous material gives few contributions to paleoenvironmental studies, but in the seeds case it gives important data about its ecology.

This importance is due to the biology of the seeds that define them as dispersal structures, as well as spores and pollen. According to Scott and Collinson (1983 p. 116), "some plant organs may be incorporated into the sediment as part of the natural life cycle. Water plants, for instance, shed their seeds, which may at first float, but then sink and become buried in the sediment. Hence, at least in the case of records of the seeds attached to fructification, we have, for the majority of the specimens analyzed in this study, parautochthony or allochthony. This classification will be possible through the analysis of the depositional site, the morphology of the seeds and its abundance in the record.

\section{RESULTS}

\section{GYMNOSPERMAE}

Semina Incertae Sedis

Samaropsis gigas Souza and Iannuzzi 2007

Figures 2A, B 
Material: MP-Pb 3022; 3032; 3045; 3230; 3420; 3423; 3429; 3656; 3660 A/B; 3662; 3691 A, 3742; 3957; 3963; 3965; 3986; 3987; 3988; 3989; 3990; 3991; 3992 A/B; 3993 A; 3994; 3995; 3996.

Locality: Morro do Papaléo outcrop, in Mariana Pimentel, RS. (Figure 1)

Occurrence: Fossiliferous level N4, uppermost Itararé Group, and fossiliferous level N8, Rio Bonito Formation, according to Iannuzzi et al. $(2003,2006)$.

Age: Early Permian (Late Sakmarian - Early Artinskian).

Description: Platispermic seed, large size, length about $50 \mathrm{~mm}$ and width between $30-40 \mathrm{~mm}$. The most part of the seed size corresponds to the nucellus, which retains the nutritive reserves of the embryo. Well-developed testa, differentiated in three distinct layers: the endotesta, inner and fibrous, involving the nucellus; the sclerotesta in the middle; and the sarcotesta, outer, widest and apparently fleshy.

Analysis of Biological Features: These species measures are considerably larger than the average of the seeds recovered from this outcrop (and others of the Paraná Basin). So, seeds must have morphological adaptations to be abioticallydispersed by agents as wind and water.

However, in this case, the biotic dispersal seems to be unlikely. Regarding the biotic dispersal by epizoochory or endozoochory, Samaropsis gigas would need animals with a considerable size to be able to carry or ingest it without damaging the embryo. However, in the Lower Permian of Rio Grande do Sul, there seems to not have animals enabled to be the dispersal agents of S. gigas.

According to Tiffney (2004), during "the Pennsylvanian and Early Permian, herbivores occur within $10^{\circ} \mathrm{N}$ and $10^{\circ} \mathrm{S}$ of the Paleoequador, and spread beyond this belt only in the Late Permian". Therefore, in the Lower Permian of Rio
Grande do Sul, the dispersal fauna was quite limited. According to Richter (2000) there is only the possibility to occur some fishes whose are associated to marine deposits of this interval.

Regarding the amniotes group, only the mesosaurids have their records at the end of the Eopermian. According to Araújo-Barberena et al. (2002), the mesosaurs occur in the Irati Formation, which is characterized by shallow marine environments.

The occurrence of Samaropsis gigas, at first restricted to rocks from the uppermost Itararé Group, and its scarce record in the upper-middle portion of the Rio Bonito Formation, move away the possibility of coexistence of these two groups since these deposits are distant some million years from the Irati Formation. Moreover, according to some authors, the mesosaurid reptiles fed on plankton (Bertini 2004) or, as suggested by a most recent study (Modesto 2006 p.366), "the morphology and the organization of the dentition strongly suggest a specialization for small, relatively soft prey" as freeswimming, shrimp-like notocaridids. Seeds were not included in the feeding habits of these animals.

On the other hand, regarding the dispersal structures, $S$. gigas has two important features: the presence of an inner and fibrous testa involving the nucellus, called "endotesta" by Souza and Iannuzzi (2007), which is preserved in all specimens (Figure 2B), and a well-developed external layer "sarcotesta".

The analysis of this first feature leads us to the interpretation that this was an appropriate tissue for flotation, with spaces between fibers probably filled with air. According to Van der Pjil (1969), the low specific weight is the most frequent cause of flotation caused by air spaces, albumen or cotyledons lightness, or the presence of a tissuetype cork. With the fibrous endotesta, the seed, in the dispersal process, would fall into the water body and float to find a suitable environment for its establishment and germination. In turn, the role of the sclerotesta may be the protection of 
the nucellus, because despite its little thickness, it appears preserved in all specimens, indicating its high resistance (Figure 2B).

The sarcotesta, therefore, interpreted as the second relevant feature to the analysis, is the most developed and external layer (Figure 2B). Due to its apparent fleshy consistency, it does not show efficiency for the anemochoric transportation, once the well-developed nucellus would require a proportionately larger testa and, preferably, membranaceous wings that would make it more aerodynamic to be carried out by the wind.

The bilateral symmetry of the sarcotesta of S. gigas appears to have had the task of contributing to the hydric stability of the seed while it floats on the water. Nevertheless, a fleshy consistency may suggest dispersal by vertebrates. However, as discussed above, herbivorous vertebrates that would be able to make such dispersal seem to not have existed in this period.

Therefore, in a study developed by Dehgan and Yuen (1983) with seeds of the genus Cycas L., the same three coats described for S. gigas were shown, being the inner coat the most responsible for the seed buoyancy. In addition, the sarcotesta of these seeds, according to the authors, would seal the seed against the water action by waxy and thick tissue, preventing the rapid flooding of the interior of the seed. This function, however, cannot be measured for this fossil record and remains only as speculation.

Finally, Tiffney (2004) suggested that the fleshy consistency of the structures of the diaspore may serve to protect the nucellus against the unwanted action of insects. It should be noted that specimens of Samaropsis sp. 1, with similar morphology to S. gigas, also described by Souza and Iannuzzi (2007) for the same deposits, have in its structure preserved marks of the action of sucking insects, supporting the theory of the protection of the nucellus suggested by Tiffney (2004). This possibility, however, must be better investigated in future studies that certify the evidence of insect-plant interactions in these seeds.
Analysis of Taphonomic Features: The samples containing S. gigas were recovered from Morro do Papaléo outcrop. The well-preserved specimens, the presence of diagnostic features and the richness of details allow an accurate study of these seeds. Furthermore, the amount of specimens is greater than the average usually found to fossil seeds. Thus, S. gigas is among the species more often recorded from this outcrop.

The main fossiliferous level of occurrence of S. gigas is the N4, which is described at the stratigraphic profile proposed by Iannuzzi et al. (2003, 2006) (Figure 1). This level is stratigraphically situated at the uppermost portion of the Itararé Group, and it is composed of light grey to reddish, horizontally laminated siltstones and siltymudstones, which are characteristic of sedimentary environments with low-energy, where there is predominantly particulate matter deposited by suspension and almost no water flow. According to Iannuzzi et al. (2003, 2006), this level is interpreted as a proximal environment water body margin as lakes or lagoons.

The quality of preservation of the material, the absence of abrasion marks or breaks for transportation especially in well-developed sarcotesta, the characteristics of the depositional site described above and the significant amount of specimens indicate a little transportation of these structures beyond their original habitat. Iannuzzi et al. (2007) classified the plant assemblages from which $S$. gigas was recovered $(=\mathrm{N} 4 \mathrm{~b})$ as being parautochthonous in terms of transportation.

The fossiliferous level N8 corresponds to the Rio Bonito Formation, Guatá Group. This level is composed by white to light-grey, massive or horizontally laminated silty-mudstone (Iannuzzi et al. 2003, 2006). This layer is interbedded with white, coarse- to very coarse- grained tabular sandstones, with undulate and erosive contacts. The depositional sites are typically of floodplains and the seeds record seems to be correlated with 
some flooding times, justifying the scarce records of seeds for this level. The flora assemblage found in this level is considered parauthochtonous (N8b,c) (Iannuzzi et al. 2007). This interpretation is supported by taphonomic features since seeds are naturally dispersed structures and no specimens were found attached to other parts of the plant.

Interpretations: From the results obtained by the analysis of biological and taphonomic features of the specimens of $S$. gigas, it was concluded that the dispersal syndrome adopted by this species was the hydrochory. The endotesta, with its spongy tissue, seems to be the most adapted dispersal structure (Table I).

It seems that the parent plant of $S$. gigas inhabited the margins of the water bodies, being dispersed by the water, which explains the abundance of this species in sediments related to lagoon and lacustrine marginal deposits.

Thus, the seed size suggests the motherplant as a typical later-successional plant and, as discussed herein, typical of closed, lightpoor communities adapted to a high amount of litter. (Tiffney 1986, 2004, Eriksson et al. 2000, Jakobsson and Eriksson 2000).

Botanical affinity: In Level N4, where the seeds are often found, there are other remains as leaves classified in the morphogenera Gangamopteris, Glossopteris, ?Dicranophyllum, Cheirophyllum, Kawizophyllum and Cordaites, which are found with rhizomes, stems and leafy shoots related to Phyllotheca-type (Iannuzzi et al. 2007). Records of leaves of Gangamopteris, Glossopteris, Ginkgophytopsis, Kawizophyllum and Cordaites, lycopsid stems of Brasilodendron-type and CyclodendronI-type, fronds classified as Pecopteris, Sphenopteris, Neomariopteris and Asterotheca, and fructifications of Arberia-type are associated to the fossiliferous level N8. From the analysis of the taphonomic data available, any inference about the parent-plant of $S$. gigas would be speculation, once the specimens recovered are dispersed in the sediment without a connection with other plant part. Taking into account the information available in the literature for the groups registered herein, the cordaitaleans would be more indicated as mother-plants because it would be the only ones, in principle, to have large seeds similar to those described herein (Taylor and Taylor 1993).

\section{Samaropsis kurtzii Leguizamon 1971}

\section{Figure 2C}

Material: MP-Pb 2746; 2824ab.

Locality: Morro do Papaléo - Lavina outcrop, Faxinal Section by Souza and Iannuzzi (2009), approximately equivalent to the level N2 of Iannuzzi et al. (2003, 2006). (Figure 1)

Occurrence: Uppermost Itararé Group.

Age: Early Permian (Late Sakmarian).

Description: Platispermic seed, large size, with approximately $24 \mathrm{~mm}$ length and $22 \mathrm{~mm}$ width. Nucellus is about $13 \mathrm{~mm}$ length and $12 \mathrm{~mm}$ width. Well-developed testa, symmetrical, with a membranaceous aspect and reticulated network in the whole extension.

Analysis of Biological features: Even considerably smaller than S. gigas Souza and Iannuzzi, Samaropsis kurtzii Leguizamon presents a large seed in its overall dimensions. However, this size is due to the presence of symmetrical well-developed wings disposed longitudinally in relation to the central body of the seed (nucellus).

The presence of these wings with membranaceous appearance and reticulated networks seems to indicate the dispersal syndrome adopted by the species (Figure 2C). This analysis indicates an adaptation to favor the wind as the abiotic dispersal agent (Van der Pjil 1969, Howe and Smallwood 1982). Hence, the aerodynamics probably contributes to the transportation of the seed by wind, which allows its occupation and establishment in other sites. 
Analysis of Taphonomic features: The Morro do Papaléo - Lavina outcrop, identified by Souza and Iannuzzi (2009) as Faxinal Section, received little attention regarding its facies description and paleoenvironmental interpretation. However, it is knew from the lithology and floristic assemblage that it corresponds to levels correlated to those described by Iannuzzi et al. $(2003,2006)$ to the uppermost Itararé Group, specifically subjacent to level N4 and approximately equivalent to level N2 (Figure 1).

The level in which are found the plant remains in the Faxinal Section consists of horizontally bedded, finely laminated siltstones, beige and medium grey in color, typical of low-energy depositional environments. Andreis et al. (1979) interpreted these deposits as being lacustrine (or lagoonal authors op.) environments of shallow but stable waters. The specimens of $S$. kurtzii in this outcrop are well preserved, allowing a detailed analysis of their morphology even though there are only two individuals.

Due to the small amount of material and the dispersal capability evidenced by the winged structure of S. kurtzii, it would probably be a parautochthonous record or even allochthonous, with pre-burial transportation. However, it is necessary to analyze the depositional site from which the holotype of this species was recovered in Argentina to be sure about these inferences.

The material-type of $S$. kurtzii described by Leguizamon (1971) was recovered in Bajo de los Vélez, Argentina, from the Permo-carboniferous period. According to Azcuy et al. (1987), these outcrops are dispersed in a Great Rift Valley, and the levels with plant remains are preserved in the Membro Pallero. Their deposit consists of darkgrey mudstones and was generated in lacustrine environments, where the plants remains would have reached the depositional site by flotation from the margins of a water body. According to these authors, the interpretation of the fauna and flora preserved suggests the existence of a climate with intermediate moisture probably in the vicinity of upland forests full of cordaitaleans.

Interpretations: Considering the scarce records of this species, as in this study regarding the Argentinean material, the morphological characteristics already described and the similarity found among the depositional sites where this species occurs, it is possible to infer that the mother-plant of $S$. kurtzii lived in distal areas in relation to the water body, and it had the wind as its main dispersal agent. Moreover, the water could have a role on its dispersal, such as the case of some current seeds with membranaceous sarcotesta. According to Remy (1975), the plants that live in areas far from water bodies have a scarce record because a huge transport is required to incorporate them into the sediment. These plants are classified as mesophilic and xenophile.

Finally, by the analysis of the seed dimensions, S. kurtzii is among the intermediary plants probably more competitive than Samaropsis gigas and typical of early-successional species, with tolerance to different light conditions (Tiffney 1984, Jakobsson and Eriksson 2000).

Botanical affinity: Leaves records of Glossopteris communis and Gangamopteris spp., remains of stems (Paracalamites-type) and leafy shoots related to sphenophytes (Phyllotheca and Stephanophyllites), as well as fragmented fronds of Botrychiopsis plantiana, have been recovered from the same exposure from which comes $S$. kurtzii (Souza and Iannuzzi 2009). However, in this record there are no specimens of $S$. kurtzii attached to other structures, which could give information about the parent plant. On the other hand, as well as $S$. gigas, due to $S$. kurtzii size, the cordaitalean group could be considered candidate to be the mother-plant of this seed-type (Taylor and Taylor 1993). However, some coniferous cannot be neglected, whereas the anemochory is relatively 
common in this group. Both cordaitalean and the coniferous groups are registered in Bajo de los Vélez, Argentina (Archangelsky 2000). However, in Brazil, the occurrence of Cordaites leaves is common in correlated levels of the Faxinal Section (Iannuzzi et al. 2003, 2006, 2008).

\section{Samaropsis aff. S. millaniana \\ Oliveira and Pontes 1976 \\ (in Souza and Iannuzzi 2007)}

Figures 2D, E

Material: MP-Pb 3941; 3944 A/B; 3946 A-E; 3947; $3951 \mathrm{~A} / \mathrm{C} ; 3954 \mathrm{~B} ; 4030$ A/B.

Locality: Morro do Papaléo outcrop, Mariana Pimentel, RS. (Figure 1)

Occurrence: Fossiliferous level $8(=\mathrm{N} 8)$, Rio Bonito Formation, according to Iannuzzi et al. (2003, 2006).

Age: Early Permian (Early Artinskian).

Description: Small seed, striated, length about $6-$ $8 \mathrm{~mm}$ and width about $5-7 \mathrm{~mm}$. Rounded shape with nucellus measures about $5-7 \mathrm{~mm}$ length and $3-5 \mathrm{~mm}$ width. Undeveloped testa with an insertion scar at the basal portion.

Analysis of Biological Features: Small seed without dispersal structures evident. The fibrous appearance indicates a high resistance of the structure. Hence, the striated testa, despite being poorly developed, seems to has an effective protective role of the nutritive reserve and embryo against a probable hostile environment (Van der Pjil 1969).

The absence of dispersal structures generates two hypotheses of analysis. The first one is that the seed is biotically-dispersed and the morphological characters that would help to highlight the syndrome have not been preserved. The second one is that the species associates different dispersal strategies.

Therefore, it is important to analyze the context in which the records occurred, the likely environment of life and the possible dispersal agents. Regarding the first hypothesis, the analysis on biotic dispersal has some limitations known to paleontology, as non-preservation of colors, tastes and odors. Because these characteristics are directly related to some biotic dispersal syndromes, some identifiable seeds must be found associated to an animal gut or its coprolites to confirm this hypothesis.

Moreover, as discussed regarding S. gigas, the presence of potential vertebrate dispersal agents is limited since the vast majority of known species of amniotes have not been recorded for this interval in the Paraná Basin. However, S. aff. S. millaniana is significantly smaller than $S$. gigas, which makes possible the hypothesis of dispersal by fish.

The fish in the Paleozoic probably acted as generalist dispersal agents since the Carboniferous (Tiffney 1984). It is known that, at the beginning of the Permian, in the underlying deglational sequences found in the Paraná Basin, there is good evidence for the existence of fish-shaped vertebrates, especially the group of paleoniscids, which occurred almost over the entire period (Richter 2000). With the confirmation of this hypothesis, the structures of the striated testa would be responsible for protecting the nutritive reserve and embryo while the seeds were passing through the gut of the animal. However, there are problems of record to confirm this hypothesis, as emphasized earlier.

The second hypothesis concerning the different types of dispersal syndromes seems plausible. However, some possibilities can now be eliminated. The first unlikely abiotic dispersal syndrome is anemochory since the seed is relatively large to be dispersed by wind without having specialized structures. The second, for reasons not so obvious, is the autochory due to the presence of a dense and sharp scar of insertion of the seed in the mother- 
plant, which gives to it a strong support and avoids its dispersion by a simple physical alteration of fructification (Van der Pjil 1969).

Therefore, in terms of disconnection from the mother-plant, the seed does not seem to have differentiated strategies. It seems that with the maturing of the seeds, they were disconnected from fructification due to the action of gravity, i.e. barochory (Van der Pjil 1969).

Since the seeds are scattered into the substrate, two other strategies could be occur. The first would be the biotic dispersal, as previously mentioned. The second would be the hydrochory since the fibrous structure might provide some resistance to rapid flooding (Van der Pjil 1969) and allows the seed to float through the water body until reaching environments suitable to its establishment and germination.

Analysis of Taphonomic Features: As well as $S$. gigas, $S$. aff. S. millaniana was recovered from Morro do Papaléo outcrop, but its occurrence is restricted to level N8 (Figure 1) described by Iannuzzi et al. (2003, 2006). Most of the specimens is well preserved, with diagnostics structures evident.

The amount of preserved material is relatively high when compared with other morpho-types found in the outcrop. They are preserved as impressions and occur disconnected from other structures.

The fossiliferous level N8 was presented herein for $S$. gigas. The depositional site is typically composed of floodplains and the record of $S$. aff. S. millaniana can correspond to small lakes, with stable waters, which occur near the river channel (= "overbank lakes"), interspersed with higherenergy environments represented by sandstones. According to Iannuzzi et al. (2007), the latter may represent the record of the leakage of the channel and, therefore, a record of the proximal floodplain. The flora assemblage found in this level is considered parauthochtonous (Iannuzzi et al. 2007).

The state of preservation, the absence of abrasion scars and breaks produced by the transport of the material show the high resistance of these seeds or the little transportation suffered by them. On the other hand, the presence of dispersed specimens in the same sample makes unlikely that these structures have passed through the gut of some fish and then re-deposited all together in one place.

In this sense, the record shows that the action of selection by transportation in which the seeds, at the time of flood, were transported and deposited together in more distant sites due to their similar buoyancy, is probable to occur. This material thus appears to be parautochthonous (Bateman 1991).

However, considering that the specimens collected and described by Souza and Iannuzzi (2007) were classified as similar to Samaropsis millaniana Oliveira and Pontes, it is important to extend the analysis proposed herein to the material-type.

S. millaniana occurs in Bainha, Hospital and São Marcos outcrops (Oliveira and Pontes 1976). These outcrops are recovered from "Irapuá Bed", Rio Bonito Formation, in Santa Catarina State, and correspond to a single stratigraphic interval. According to Iannuzzi (2002), the fossiliferous level at Bainha outcrop, entitled "facies B", is composed of grayish to reddish siltstone, with incipient plane-parallel stratification (indicated by fossils) and abrupt contact with "facies C" (informally called the "siltstone Irapuá"). These features are characteristic of low-energy water bodies generated in a floodplain. Therefore, the facies of the record of the material-type of $S$. millaniana is very similar to the level N8 of Iannuzzi et al. (2003, 2006), thereby facilitating comparisons between them.

Interpretations: It can be concluded that $S$. aff. S. millaniana does not have an evident dispersal syndrome and is probably disconnected from the mother-plant by the gravity action. Furthermore, through the information obtained from the taphonomic data, the fishes' action as dispersal agents seems to be unlikely. Thus, the concentration of these specimens on the sample can indicate the 
transportation suffered by the increasing of the water level and by the selection according to the size and density of seeds.

The fibrous testa confers resistance whose necessity could be justified by the environment where the mother-plant lived. In areas such as floodplains, changes in the level of water and humidity are constant, which requires the drought resistance or the rapid flooding. Thus, seeds could be transported beyond the limited space provided only by barochory. This strategy justifies the small size of the seed and indicates mother-plants with pioneering habits (Table I).

Botanical affinity: As presented to Samaropsis gigas, the fossiliferous level N8 is associated to the seeds records of leaves of Gangamopteris, Glossopteris, Ginkgophytopsis, Kawizophyllum and Cordaites, lycopsid stems of Brasilodendrontype and CyclodendronI-type, fronds classified as Pecopteris, Sphenopteris, Neomariopteris and Asterotheca, and fructifications of Arberiatype. All specimens of seeds are dispersed, with no connection to other plant parts. On the other hand, using the data available for flora combined with the characteristics of the specimens of $S$. aff. S. millaniana, a relationship of these seeds with glossopterid or ginkgoalean groups due to the small size presented by these seeds (Tiffney 1986) may be suggested. However, considering the fact that it is a record of a parauthochtonous assemblage within a flood plain, the hypothesis that other plant parts have not been preserved for several reasons cannot be discounted. (Gastaldo et al. 1995, Bateman 1991).

Cordaicarpus cerronegrensis

Souza and Iannuzzi 2009

Figures 3A, B

Material: MP-Pb 2608A - D; 2613A-E; 4392a/b A-D; 4393A.
Locality: Cerro Negro outcrop and Morro do Papaléo - Lavina, Faxinal Section de Souza and Iannuzzi (2009), correlated to the level N2 of Iannuzzi et al. (2003, 2006). (Figure 1)

Occurrence: Uppermost Itararé Group and Rio Bonito Formation.

Age: Early Permian (Late Sakmarian - Early Artinskian).

Description: Small seed, striated surface, length average of $5.5 \mathrm{~mm}$ and width average of $3 \mathrm{~mm}$. Elongated, acute apex, rounded base with a scar at the point of attachment to seed stalk. The undifferentiated testa becomes widest towards the apical portion of the seed.

Analysis of Biological Features: It is a small seed with a fibrous surface, which seems to confer a high resistance to the seed with no evident dispersal structures.

This species has (in the rock sample MP-Pb 4392ab) a record of a fructification with four seeds associated (Figure 3B). The analysis of this material moves away any possibility of autochory, whereas the fructification does not have a morphology specialized to work actively on seeds dispersion. The morphology of Cordaicarpus cerronegrensis suggests that the dispersal syndrome is barochory, such as described to $S$. aff. S. millaniana.

Associated to barochory, the anemochory seems to be other possibility of syndrome due to the small size of $C$. cerronegrensis (about $5 \mathrm{~mm}$ ). The wind becomes a dispersal agent to be considered, even for those seeds without morphological adaptations (Hughes et al. 1994). However, this possibility should be better examined since the average size of specimens is on the limit of the size proposed by Chaloner and Sheerin (1981).

Thus, as discussed for other species, the possibility of a biotic dispersal for C. cerronegrensis is limited since, regarding the fauna of this interval only fishes could act as dispersal agents. However, the presence of this syndrome is hard to be confirmed. 
Analysis of Taphonomic Features: C. cerronegrensis occurs in two outcrops, Cerro Negro and Morro do Papaléo - Lavina, Faxinal Section, near Mariana Pimentel downtown. The state of preservation of the material is good, with the specimens fully preserved.

Few prior studies have taken the Cerro Negro outcrop into account. Its stratigraphic section, according to Delaney (1964), consists of basal conglomerates (facies 1) followed upwards by finegrained sandstones and clayey-siltstones (facies 2), which are overlaid with carbonaceous shale and siltstones (facies 3), occasionally interbedded with lenses of limestone and quartz sandstones and finishing at the top with a thick covering of conglomeratic, quartz sandstones interbedded with sandy siltstones (facies 4).

The material recovered and analyzed in this study is from facies 3, which corresponds to a lowenergy depositional environment characterizing floodplains deposits in fluvial systems. This outcrop, according to Corrêa da Silva (1978), is situated in the Rio Bonito Formation and its contact surface with the Itarare Group is hidden by the vegetation.

There are also few studies of Morro do Papaléo - Lavina, Faxinal Section outcrop as mentioned to S. kurtzii. However, it was known that this outcrop corresponds to the upper portion of the Itararé Group, and its fossils were found in subjacent levels regarding the level N4 of Morro do Papaléo described by Iannuzzi et al. (2003, 2006) (Figure 1). This deposit was interpreted as typical of stable and shallow waters as those generated in lakes and lagoons (Andreis et al. 1979).

The analysis of the depositional sites and their comparison with what is recorded in the samples lead to the conclusion that, in Cerro Negro outcrop (although it represents a low-energy environment), seeds are randomly spread in the samples disconnected from fructification, which probably indicates a parautochthonous record.

In the case of Morro do Papaléo- Lavina, Faxinal Section, the record of the seeds attached to fructification indicates the minimum transport suffered by the structure because otherwise it would be quickly disconnected due to its fragility. Thus, the record on the upper portion of the Itararé Group is here interpreted as autochthonous/ parautochthonous.

Interpretations: Given the characteristics of the two depositional sites and distribution of fossil records, it is believed that the mother-plant of C. cerronegrensis lived in marginal areas regarding the water bodies, as lakes and lagoons. The material recovered from deposits of floodplain probably represents the records filled with a flood of the water bodies. The mother-plant of C. cerronegrensis was probably a pioneer plant (Table I). The dispersal syndrome associated to barochory could have been the anemochory, which, however, cannot be reliably confirmed; it would require a greater sampling effort in order to find more solid evidences in this regard.

Botanical affinity: Records of leaves of Glossopteris communis and Gangamopteris spp., stems (Paracalamites $\neg$-type) and leafy shoots of sphenophytes (Phyllotheca sp. and Stephanophyllites sp.), as well as fragmented fronds of Botrychiopsis plantiana, were found in the Morro do Papaléo - Lavina, Faxinal Section outcrop (Souza and Iannuzzi 2009). Leaves of Glossopteris and Cordaites were found at Cerro Negro outcrop. Using the known data about reproductive structures of the flora assemblage and the structural characteristics of $C$. cerronegrensis, the only group that could be mentioned as motherplant of this seed would be the glossopterid due to the small size of its seed. However, its fructification is different from that described in the literature for this group (R. Andendorff, unpublished data). This fructification has apparently not yet been described and seems to be a fragment of a fertile branch similar to those found in conifers of the Early Paleozoic. Therefore, it is not possible to infer the botanical affinity of $C$. cerronegrensis. 
Cordaicarpus truncata Souza and Iannuzzi 2009

Figures 3C, D

Material: MP-Pb 3968 A; 3969 B, C; 3972 A, B.

Locality: Morro do Papaléo outcrop in Mariana Pimentel, RS. (Figure 1)

Occurrence: Fossiliferous level 2 (= N2), uppermost Itararé Group; according to Iannuzzi et al. (2003, 2006).

Age: Early Permian (Late Sakmarian).

Description: Striated seed, acute apex and truncate base. About $8 \mathrm{~mm}$ length and $5 \mathrm{~mm}$ width. Testa is narrowest at the lateral sides and widest at the base portion where it is truncated.

Analysis of Biological Features: As C. cerronegrensis, Cordaicarpus truncata is small and does not have dispersal structures preserved. It has a fibrous surface, which gives high resistance to the seed, and a truncated base that suggests a connection with the fructification.

Specimens of C. truncata are dispersed in the sediment, with no evidence of contact with the mother-plant. These specimens are not abundant, but the majority of them has all diagnostic structures. Some specimens have some scars of degradation probably due to the action of biological agents (MP-Pb 3969A). According to Collinson, cited by Martin (1999), the seeds are resistant to mechanical degradation, and the biological degradation is the most important decomposition process acting on these structures.

Regarding the possible dispersal syndrome adopted, if the presence of a truncate base as a connection scar could be verified, the possibility of autochory would be moved away and the barochory would be the probable dispersal mechanism similar to that suggested in the case of $C$. cerronegrensis. However, this species can be attached to the fructification by the apex portion, as occurs with Araucaria angustifolia (Bertol.) Kuntze.
Hence, as an associated syndrome, the anemochory does not seem to be feasible because of the size of the diaspore. It would require the presence of a dispersal structure such as plumes or wings to facilitate the movement by the wind (Chaloner and Sheerin 1981). However, as discussed for other species, there is the possibility of biotic dispersal for $C$. truncata even though it is quite limited in terms of vertebrates. If we consider it as a viable possibility, the probable dispersal agent would be some kind of fish, and the fibrous structure that surrounds the central body of the seed (nucellus) would be responsible for the protection of the nutritive reserve and embryo during the passage through the gut of the animal.

Analysis of Taphonomic Features: C. truncata occurs in the Morro do Papaléo outcrop located in the municipality of Mariana Pimentel. The specimens recovered from this outcrop were found preserved as impressions/compressions.

The fossiliferous level (N2) in which C. truncata occurs is described at the stratigraphic profile proposed by Iannuzzi et al. $(2003,2006)$ and corresponds to the uppermost portion of the Itarare Group (Figure 1). This fossiliferous level consists of horizontally bedded heterolithic units composed of siltstones and light to medium grey, finely laminated shales typical of low-energy depositional environments, which correspond to lagoonal to lacustrine systems (Iannuzzi et al. 2003, 2006)

The quality of the material with some delicate structures preserved, the characteristic of the depositional environment and the absence of dispersal structures denote the little transportation of these structures. Hence, they are considered parautochthonous remains.

Interpretations: Due to the small amount of specimens recovered, the interpretations are even more incipient. Considering that $C$. truncata is a small seed, it can be inferred that the mother-plant should be a pioneer plant (Table I). 
It could be inferred from the scarce record that these species lived in distal areas regarding the water body, and the degradation of some specimens could be the result of the ephemeral exposure of these seeds to the humidity. These seeds would be subjected to the subsequent removal caused by variations in the level of water bodies, thus facilitating the prior performance of decomposers.

By contrast, the mother-plant could live near the water bodies. Thus, the fish dispersal would act as a syndrome associated to barochory. In this case, the degradation would be the result of the seed passing through the gut of the fish.

A greater sampling effort is needed to verify these hypotheses in order to try to find new evidences about both possibilities. Furthermore, the studies with fishes in the southern Paraná Basin must be increased, especially about their feedings habit.

Botanical affinity: Studies performed by Iannuzzi et al. (2007) indicated the presence of impressions of fronds of Botrychiopsis sp. and leaves of Glossopteris, Gangamopteris and Cordaites. However, in the samples with specimens of $C$. truncata, there is not the record of other plant remains. Using the data present in the literature, the glossopterid group would probably be the motherplant of these seeds if considering the small size of these seeds, but these data are not conclusive.

\section{Cordaicarpus aff Cordaicarpus brasilianus \\ Bernardes-de-Oliveira et al. 2007}

$$
\text { Figures 3E, F, G }
$$

Material: MP-Pb 3233; 3674; 3682 A; 3735; 3746; 3751 A, B; 3753; 3950 A, B; 3943 A; 3962; 3964; 3966 A.

Locality: Morro do Papaléo outcrop in Mariana Pimentel, RS. (Figure 1)

Occurrence: Fossiliferous level 4 (=N4), uppermost Itararé Group; and fossiliferous levels 7 (= N7) and 8 (=N8), Rio Bonito Formation, according to Iannuzzi et al. (2003, 2006).

Age: Early Permian (Late Sakmarian EarlyArtinskian).

Description: Small seed, smooth surface and circular shape. Length average of $3.5 \mathrm{~mm}$ and width about $3 \mathrm{~mm}$. Narrow and undifferentiated testa.

Analysis of Biological Features: Small seeds without apparent dispersal structures. They are abundant in the record and are usually found scattered, except in some cases as in the sample MP-PB 3746, in which the seeds are attached to the fructification (Figure 3E).

This kind of fructification is frequently found in the record and it is classified as Arberiatype (Iannuzzi et al. 2007), which has been recovered from level N8, Rio Bonito Formation. At this fructification, the seeds are attached to the terminations forming a kind of pedicel, from which the seed will disconnect when mature probably with the help of the gravity, leaving a scar of insertion (Figura 3E, F). In this context, it seems likely that one of these dispersal syndromes is the barochory.

As an associated syndrome, concerning the seeds size, the anemochory seems to be possible (Chaloner and Sheerin 1981, Hughes et al. 1994). Furthermore, the simplicity of this morphology and its abundance in the record contribute to this inference.

Thus, the absence of a specialized tissue of protection moves away the possibility of fish dispersal - whereas these seeds would be easily degraded in the gut of animals - or the water transportation because these seeds would not have resistance to the rapid flooding and subsequent drying.

Analysis of Taphonomic Features: The specimens of Cordaicarpus aff C. brasilianus recovered from Morro do Papaléo outcrop were preserved as impressions/compressions dispersed in the sediment or associated to the fructifications of Arberia-type. 
$C$. aff $C$. brasilianus occurs in three fossiliferous levels, N4, N7 and N8, which are described at the profile proposed by Iannuzzi et al. (2003, 2006). Level N4, described herein for Samaropsis gigas, is stratigraphically situated at the uppermost portion of the Itararé Group. It corresponds to deposits of marginal environments, lagoonal or lacustrine systems, which are typically low-energy depositional environments (Figure 1).

Both levels N7 and N8 represent the same facies and are related to the Rio Bonito Formation, Guatá Group. Level N8 was also described in this study (see the analysis of the taphonomic features of $S$. gigas). The depositional environment is typical of floodplains and corresponds to small lakes with stable waters, which occur near the river channel (= "overbank lakes").

The quality of preservation of the material is variable, whereas these structures are small and without an apparent tissue of protection. The transport degree also seems to be variable, and the record of these seeds is probably autochthonous/ parautochthonous once some seeds are found attached to the fructification and others dispersed.

The specimens-type of $C$. brasilianus described by Bernardes-de-Oliveira et al. (2007) are from Toca do Índio outcrop, located at the municipality of Cerquilho, São Paulo State. This outcrop is stratigraphically situated at the uppermost portion of the Itararé Group and is composed by light-grey siltstones, mudstones and carbonaceous shales intercalated with lens and sigmoid bodies of fine grained light yellowish sandstones. The fossils are found in several levels of mudstones and siltstones, even in sandstones, but more frequently above the carbonaceous mudstones (op. cit. 2007).

This depositional site corresponds to lowenergy environments, with stable waters and an anoxic portion that favor the coal formation. Hence, the preservation of C. brasilianus is also associated with the little transportation of these structures, which must correspond to that promoted by the dispersal process of barochory added to the wind action, characterizing a parautochthonous record.

Interpretations: The fructifications of Arberiatype are frequently recovered from this outcrop. This record, in association to the seeds abundance, leads to the interpretation that the mother-plant of $C$. aff. C. brasilianus could compose the vegetation of different environments, ranging from those on the margins of water bodies to those that grow in the floodplains.

The small size of $C$. aff. C. brasilianus, besides suggesting the wind as a dispersal agent (Chaloner and Sheerin 1981, Hughes et al. 1994), also indicates that this species is typically a pioneer.

Finally, the absence of specialized dispersal structures seems to be compensated by the high seed production per individual, which explains this seed abundance in the fossil record and points to the R-strategy, which is typical of pioneer plants (Chaloner and Sheerin 1981).

Botanical affinity: The fructifications of Arberiatype have an undefined systematic position (Bernardes-de-Oliveira 1978) because, according to R. Andendorff (unpublished data), this kind of fructification was never found attached to the leaves. However, these fructifications are usually related to glossopterids in the literature (Bernardesde-Oliveira et al. 2000), and they are probably a basal form of these fertile structures into this group (R. Andendorff, unpublished data). Considering that specimens of $C$. aff. C. brasilianus were found connected to Arberia-type fructifications, it is probable that the mother-plant of these seeds is a member of the glossopterid group. Furthermore, many glossopterid leaves (Glossopteris spp. and Gangamopteris spp.) were found associated with these seeds in all the fossiliferous levels studied herein (Iannuzzi et al. 2003, 2006). However, a greater sampling effort would be needed to confirm this proposition in order to try to find some seeds connected to the fructification and attached to glossopterid leaves. 
TABLE I

Comparative table summarizing the characteristics of the species analyzed.

\begin{tabular}{|c|c|c|c|}
\hline Morphospecies & Samaropsis gigas & & 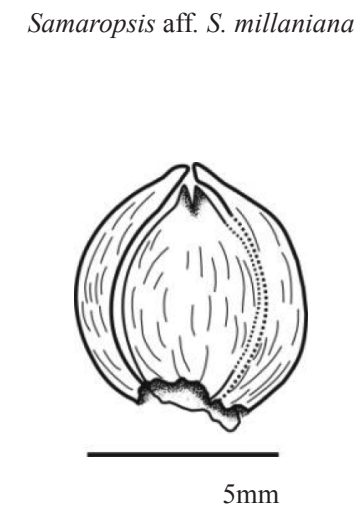 \\
\hline Dimensions & $\begin{array}{l}50 \mathrm{~mm} \text { length; } \\
30-40 \mathrm{~mm} \text { width. }\end{array}$ & $\begin{array}{l}24 \text { mm length; } \\
22 \text { mm width. }\end{array}$ & $\begin{array}{l}\text { 6-8 mm length; } \\
\text { 5-7 mm width. }\end{array}$ \\
\hline $\begin{array}{l}\text { Structures and } \\
\text { functions: Dispersal } \\
\text { Syndromes }\end{array}$ & $\begin{array}{l}\text { Fibrous/ spongy endotesta: } \\
\text { flotation; } \\
\text { Fleshy sarcotesta, } \\
\text { well-developed: protection; } \\
\text { HYDROCHORY. }\end{array}$ & $\begin{array}{l}\text { Membranaceous sarcotesta, } \\
\text { well-developed: air support. } \\
\text { ANEMOCHORY. }\end{array}$ & $\begin{array}{l}\text { Testa poorly-developed; } \\
\text { Striated: resistance. protection. } \\
\text { BAROCHORY + HYDROCHORY. }\end{array}$ \\
\hline Preservation & $\begin{array}{l}\text { Well-preserved, } \\
\text { with diagnostic features; } \\
\text { No abrasion scars or } \\
\text { breaks due to transport } \\
\text { Abundant material. }\end{array}$ & $\begin{array}{l}\text { Well-preserved, with } \\
\text { diagnostic features; } \\
\text { No abrasion scars or } \\
\text { breaks due to transport } \\
\text { Scarce material. }\end{array}$ & $\begin{array}{l}\text { Well-preserved, with } \\
\text { diagnostic features; } \\
\text { No abrasion scars or } \\
\text { breaks due to transport } \\
\text { Scarce material. }\end{array}$ \\
\hline Depositional site & $\begin{array}{l}\text { Low-energy depositional systems; } \\
\text { Floodplain of fluvial systems and } \\
\text { lagoonal or lacustrine systems. }\end{array}$ & $\begin{array}{l}\text { Low-energy } \\
\text { depositional systems; } \\
\text { Lagoonal or } \\
\text { lacustrine systems. }\end{array}$ & $\begin{array}{l}\text { Low-energy } \\
\text { depositional systems; } \\
\text { Floodplains of } \\
\text { fluvial systems. }\end{array}$ \\
\hline Transport degree & Parautochthonous. & $\begin{array}{l}\text { Parautochthonous or } \\
\text { Allochthonous. }\end{array}$ & Parautochthonous \\
\hline $\begin{array}{l}\text { Ecological group and } \\
\text { environment }\end{array}$ & $\begin{array}{l}\text { Latter-successional species; } \\
\text { Margins of water bodies. }\end{array}$ & $\begin{array}{l}\text { Early-successional species } \\
\text { Mesophilic, occupying distal } \\
\text { areas from water bodies. }\end{array}$ & $\begin{array}{l}\text { Pioneer species. } \\
\text { Proximal areas to the } \\
\text { river channel; near } \\
\text { "overbank lakes". }\end{array}$ \\
\hline Botanical affinity & Undetermined (cordaitaleans?). & $\begin{array}{l}\text { Undetermined } \\
\text { (cordaitaleans; coniferous?). }\end{array}$ & $\begin{array}{l}\text { Undetermined } \\
\text { (glossopterids, ginkgoaleans?) }\end{array}$ \\
\hline
\end{tabular}


TABLE I (continuation)

\begin{tabular}{|c|c|c|c|}
\hline Morphospecies & $\frac{2}{2 \mathrm{~mm}}$ & Cordaicarpus truncata & Cordaicarpus aff C. brasilianus \\
\hline Dimensions & $\begin{array}{l}5.5 \mathrm{~mm} \text { length; } \\
3 \mathrm{~mm} \text { width. }\end{array}$ & $\begin{array}{l}8 \mathrm{~mm} \text { length; } \\
5 \mathrm{~mm} \text { width. }\end{array}$ & $\begin{array}{l}3.5 \mathrm{~mm} \text { length; } \\
3 \mathrm{~mm} \text { width. }\end{array}$ \\
\hline $\begin{array}{l}\text { Structures and } \\
\text { functions: Dispersal } \\
\text { Syndromes }\end{array}$ & $\begin{array}{l}\text { Without dispersal structures } \\
\text { preserved; } \\
\text { Small seeds; } \\
\text { Striated surface: resistance; } \\
\text { BAROCHORY + Undetermined. }\end{array}$ & $\begin{array}{l}\text { Without dispersal structures } \\
\text { preserved; } \\
\text { Truncate base; } \\
\text { Striated surface: resistance; } \\
\text { BAROCHORY + Undetermined. }\end{array}$ & $\begin{array}{l}\text { Without dispersal structures } \\
\text { preserved; } \\
\text { Small seeds; } \\
\text { Attached to fructifications } \\
\text { of Arberia-type. } \\
\text { BAROCHORY + ANEMOCHORY. }\end{array}$ \\
\hline Preservation & $\begin{array}{l}\text { Well-preserved, } \\
\text { with diagnostic features; } \\
\text { Seed attached to fructifications; } \\
\text { Abundant material. }\end{array}$ & $\begin{array}{l}\text { Variable preservation; } \\
\text { Resistant structure; } \\
\text { Scarce material. }\end{array}$ & $\begin{array}{l}\text { Variable preservation; } \\
\text { Seed attached to fructifications; } \\
\text { Abundant material. }\end{array}$ \\
\hline Depositional site & $\begin{array}{l}\text { Low-energy depositional systems; } \\
\text { Floodplain of fluvial systems and } \\
\text { lagoonal or lacustrine systems. }\end{array}$ & $\begin{array}{l}\text { Low-energy } \\
\text { depositional systems; } \\
\text { Lagoonal or } \\
\text { lacustrine systems. }\end{array}$ & $\begin{array}{l}\text { Low-energy } \\
\text { depositional systems; } \\
\text { Floodplains of fluvial systems and } \\
\text { lagoonal or lacustrine systems. }\end{array}$ \\
\hline Transport degree & $\begin{array}{l}\text { Autochthonous or } \\
\text { parautochthonous. }\end{array}$ & Parautochthonous & $\begin{array}{l}\text { Autochthonous or } \\
\text { parautochthonous. }\end{array}$ \\
\hline $\begin{array}{l}\text { Ecological group } \\
\text { and environment }\end{array}$ & $\begin{array}{l}\text { Pioneer species. } \\
\text { Margins of water bodies. }\end{array}$ & $\begin{array}{l}\text { Pioneer species. } \\
\text { Undetermined. }\end{array}$ & $\begin{array}{l}\text { Pioneer species. } \\
\text { From margins of water bodies to } \\
\text { distal areas in the floodplain. }\end{array}$ \\
\hline Botanical affinity & Undetermined. & Undetermined (glossopterids?). & Glossopterids \\
\hline
\end{tabular}




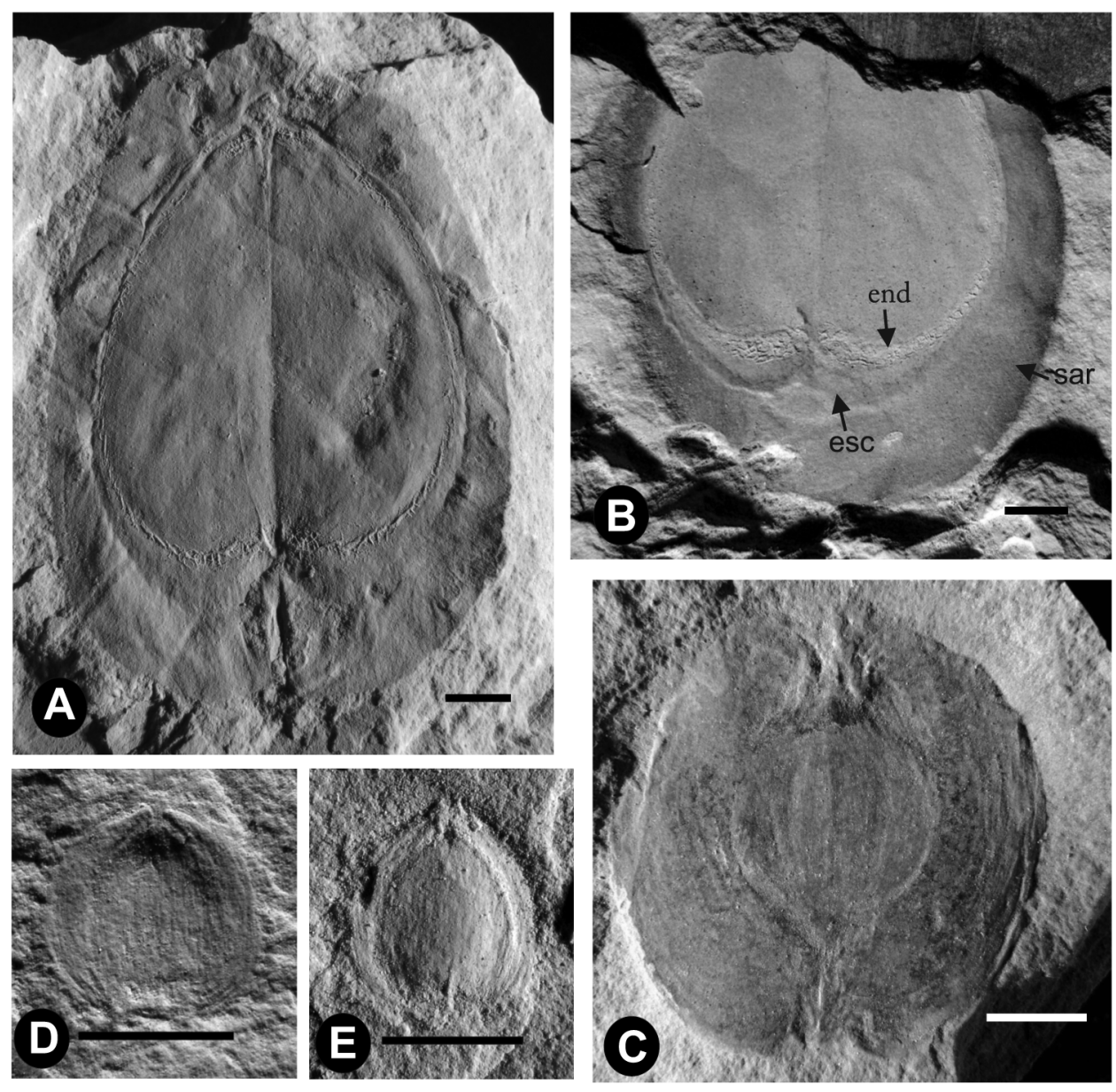

Figure 2: A, MP-Pb 3992, Samaropsis gigas, complete specimen; B, MP-Pb 3662, S. gigas, detail of the basal portion showing the three seed coats: endotesta, sclerotesta and sarcotesta; C, MP-Pb 2824a, Samaropsis Kurtzii, showing a well-developed membranaceous sarcotesta; D-E, MP-Pb 3941, MP-Pb 3946D, Samaropsis aff. S. millaniana, complete specimen. Abbreviations: end, endotesta; esc, sclerotesta; sar, sarcotesta. Scale bars: $5 \mathrm{~mm}$. 

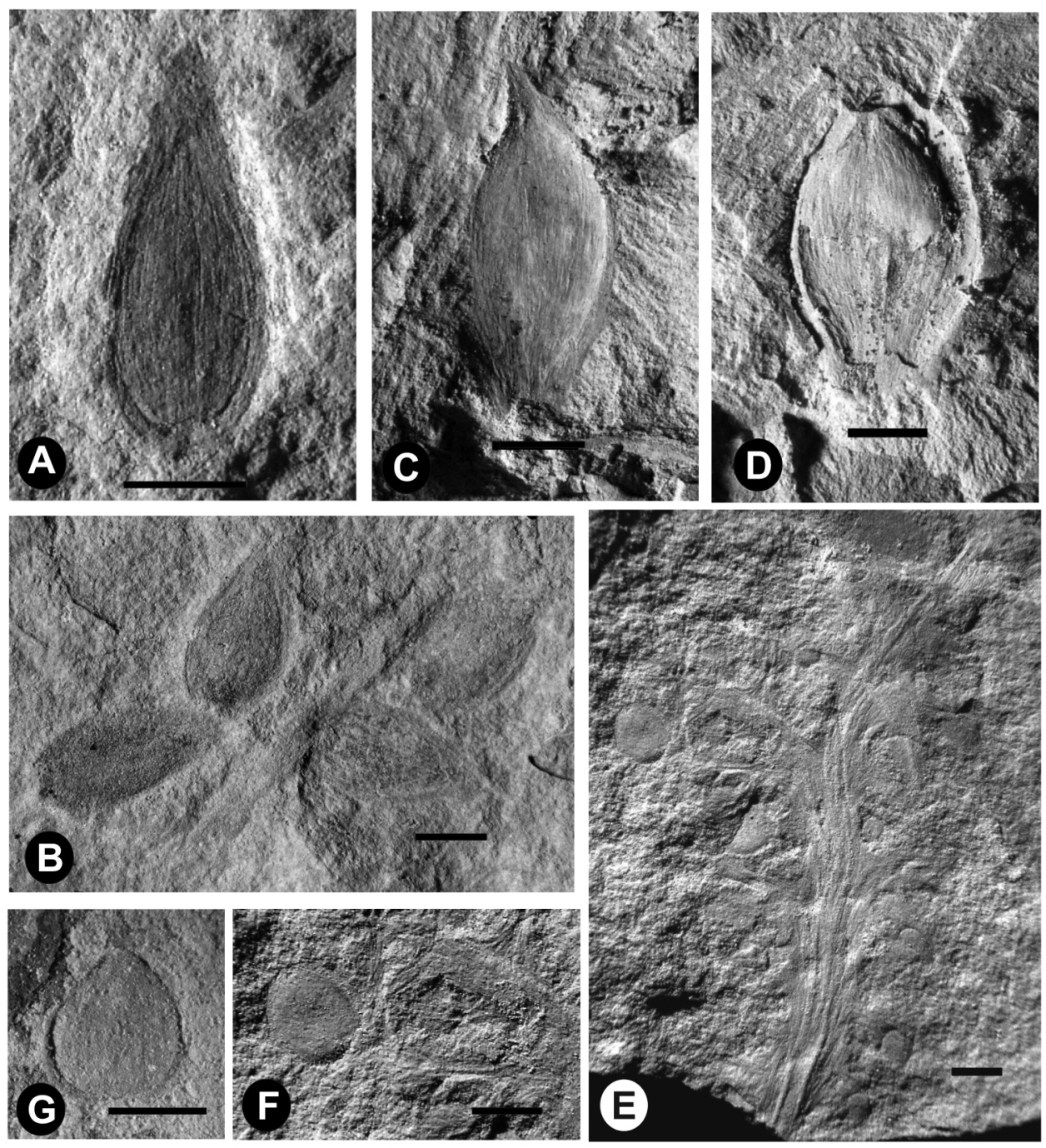

Figure 3: A, MP-Pb 2808C, Cordaicarpus cerronegrensis, complete specimen; B, MP-Pb 4392b, Cordaicarpus cerronegrensis, fructification with seeds associated; C, MP-Pb 3969B, Cordaicarpus truncata, complete specimen; MP$\mathrm{Pb}$ 3969A; D, Cordaicarpus truncata, specimen with scars of degradation; E, MP-Pb 3746, Cordaicarpus aff. C. brasilianus, specimens associated with the Arberia-type fructification; F, MP-Pb 3746, Cordaicarpus aff. C. brasilianus, specimen details; G, MP-Pb 3682A, Cordaicarpus aff. C. brasilianus, complete specimen. Scale bars: $2 \mathrm{~mm}$. 


\section{CONCLUDING REMARKS}

The use of seeds as a tool in the search for understanding the biology of the fossil plants, their strategies of reproduction, as well as their habit and habitat, seems to be practicable, but also essential for studies that aim to contribute to the paleoenvironmental and/or local flora reconstruction. Although incipient, this analysis provides information that tends to be more conclusive than other Paleobotanical studies.

However, it is important to have a good record not only in preservational terms, but also in the amount of analyzed material and well-done taxonomic and taphonomic studies, once this information make comparisons viable and increase the fossil seeds database.

The analysis of the dispersal syndromes and dispersal agents of seeds from the Lower Permian of Rio Grande do Sul allows the identification of three kinds of dispersal syndromes for six morphospecies analyzed, which are: hydrochory for Samaropsis gigas, anemochory for Samaropsis kurtzii, and barochory for Samaropsis aff. S. millaniana, Cordaicarpus cerronegrensis, Cordaicarpus truncata and Cordaicarpus aff. C. brasilianus. Furthermore, it was possible to organize spatially these morphospecies. The most significant result was found to $S$. gigas, which indicates that the mother-plant lived near water bodies, and to $S$. kurtzii, with its mother-plant occupying distal environments regarding water bodies, showing a mesophilic habit. Concerning the taxonomy, the conclusive results are modest. Cordaicarpus aff. $C$. brasilianus can be considered as a probable seed of the Glossopteris group due to its connection with a fructification of Arberia-type. Hence, the glossopterids are interpreted as generalists, investing in the amount of seeds per individual in detriment of specialized morphologies and characterizing it as pioneer species.

Considering the analysis realized herein, it is expected that this study may contribute to stimulate new studies by increasing the discussion about this theme. Thus, it is essential to expand the database of the taxonomic classifications of seeds, being vital that the paleobotanical researchers begin to pay more attention to these dispersal structures.

\section{ACKNOWLEDGMENTS}

The authors are thankful to F. F. Lopez (DPE-IGUFRGS) for the excellent photographic material; to Conselho Nacional Desenvolvimento Científico e Tecnológico (CNPq proc. 309322/2007-3 and 483463/2007-8) and Fundação de Amparo à Pesquisa do Estado do Rio Grande do Sul (FAPERGS proc. 04/1066-0) for the financial support.

\section{RESUMO}

A Análise morfológica das sementes tem sido um importante objeto em estudos ecológicos modernos, uma vez que fornece evidências sobre a biologia e as adaptações das plantas-mãe de sementes. Entretanto, este tipo de estudo tem sido restrito a ecologia de plantas modernas e é raramente utilizado em interpretações de dados paleozóicos. A partir do entendimento da análise das sindromes de dispersão como uma importante ferramenta para reconstruções paleoecológicas, este estudo oferece uma primeira abordagem utilizando essa ferramenta com sementes do Permiano Inferior do Sul da Bacia do Paraná, no Rio Grande do Sul. Baseado em sementes previamente classificadas e utilizando seus dados biológicos e tafonômicos, a síndrome de dispersão foi interpretada, e a classificação das sementes nos grupos successionais (pioneira, secundária inicial ou secundária tardia) foi sugerida. Sete morfoespécies foram analisadas: Samaropsis gigas, representando uma espécie de secundária-tardia, vivendo próximo a corpos d'água, com síndrome de dispesão hidrocórica; Samaropsis kurtzii, típica espécie de sucessão secundária inicial, apresentando a anemocoria como síndrome de dispersão e habitando áreas distantes em relação a corpos d'água; Samaropsis aff. S. millaniana, Cordaicarpus aff. C. brasilianus, Cordaicarpus cerronegrensis e Cordaicarpus truncata com características típicas 
de plantas pioneiras, sendo a barocoria sua principal síndrome de dispersão com outras síndromes associadas.

Palavras-chave: Samaropsis, Cordaicarpus, síndromes de dispersão, grupos ecológicos, Permiano Inferior, Bacia do Paraná.

\section{REFERENCES}

ANDREIS RR, CAZZULO-KLEPZIG M, GUERRA-SOMMER M AND MARQUES-ToIGO M. 1979. Interpretação paleoambiental e estudo paleobotânico e palinológico do Grupo Itararé, na área de Faxinal, Município de Guaíba, RS. In: SIMPÓSIO DE GEOLOGIA DO NORDESTE, IX. Atas, Natal, p. 65-77.

ARAÚJO-BARBERENA DC, LACERDA FILHO JV AND TIMM LL. 2002. Mesossauro da Serra do Caiapó (Montividiu), GO: Um vertebrado fóssil típico do Paleozóico Superior, importante na história da Deriva Continental. In: SCHOBBENHAUS C, CAMPO DA, QUEIROZ ET, WINGE $M$ and BEBERT-BORN MLC (Eds), Sítios Geológicos e Paleontológicos do Brasil, Brasília: DNPM/ CPRM - Comissão Brasileira de Sítios Geológicos e Paleobiológicos (SIGEP) 1: 81-85.

ARCHANGELSKY A. 1995. Patagosperma lubeckense, nueva semilla de gimnosperma del permico inferior de La província de Chubut. Implicancias paleobiologicas. Ameghiniana 32(4): 351-357.

ARCHANGELSKY A. 2000. Estúdio sobre semillas neopaleozoicas de Argentina. Bol Acad Nac Cienc, Cordoba, Argentina, Tomo 64: 80-115.

AZCUY CL, ANDreis RR, CUERDA A, HÜNICKEN MA, PENSA MV, VALENCIO DA AND VILAS JF. 1987. Cuenca Paganzo. In: ARCHANGELSKY S (Ed), El Sistema Carbonífero em La República Argentina. Cordoba, República Argentina, 383 p.

Bateman EM. 1991. Palaeoecology. In: CLEAL CJ. Plant fossils in geological investigation. The Palaeozoic. London: Ellis Horwood Limited, p. 34-116.

BERNARDES - DE-OliveIRA MEC. 1978. Frutificações de Pteridospermófitas Eogondvânicas da Camada Irapuá, Formação Rio Bonito, nos arredores de Criciúma, SC. In: XX CONGRESSO BRASILEIRO DE GEOLOGIA, Anais... Recife 2: 986-1001.

BERNARDES-DE-OliveIRA MEC, CASTRO-FernANDES MC, TEWARI R AND RiCARDI-BRANCO F. 2007. Platyspermic seeds from the Early Permian of Paraná Basin, Brazil. Palaeobotanist 56: 1-19.

BERNARDES-DE-OLIVEIRA MEC, RICARDI-BRANCO F AND RÖSLER O. 2000. As estruturas reprodutivas de Glossopterídeas na sucessão das tafofloras Permianas da Bacia do Paraná, Brasil. Geociências v(nº especial): 62-68.

BERTINI RJ. 2004. Répteis. In: CARVALHO IS (Ed), Paleontologia. $2^{\text {a }}$ ed., Rio de Janeiro: Editora Interciência 1: 861 .
Chaloner WG AND SHEERIN A. 1981. The evolution of reproductive strategies in early land plants. In: SCUDDER G AND REVEAL J (Eds), Evolution Today, Proceedings..., Pittsburg, PA, p. 93-100.

CoOmes DA AND GRUBB PJ. 2003. Colonization, tolerance, competition and seed-size variation within functional groups. Trends Ecol Evol 8(6): 283-291.

CORRÊA DA SILVA ZC. 1978. Observações sobre o Grupo Tubarão no Rio Grande do Sul com especial destaque à estratigrafia da Formação Itararé. Pesquisas 9: 9-61.

DEHGAN B AND YUEN CKKH. 1983. Seed morphology in relation to dispersal, evolution, and propagation of Cycas 1. Bot Gaz 144(3): 412-418.

DELANEY PJV. 1964. Itararé outliers in Rio Grande do Sul, Brasil. Bol Parana Geogr 10/15: 161-171.

ERIKSSON O, FrIIS EM AND LÖFGREN P. 2000 Seed Size, Fruit Size, and Dispersal Systems in Angiosperms from the Early Cretaceous to the Late Tertiary. Am Nat 156: 47-58.

GANDOlfi S, LeITÃo-FilHo HF AND BEZERRA CLF. 1995. Levantamento florístico e caráter sucessional das espécies arbustivo-arbóreas de uma floresta mesófila semidecídua no município de Guarulhos, SP. Rev Bras Biol 55: 753-767.

Gastaldo RA, PfeFfERKoRn HW AND Dimichle WA. 1995. Taphonomic and sedimentologic characterization of roofshale floras. Geol Soc Am Mem 185: 341-352.

Harper JL, LOVEll PH AND MoORE KG. 1970. The shapes and sizes of seeds. Annu Rev Ecol Syst 1: 327-356.

Holz M AND SiMÕES MG. 2002. Elementos fundamentais de tafonomia. Porto Alegre: Editora da UFRGS, $231 \mathrm{p}$.

Howe HF AND SMallwoOd J. 1982. Ecology of Seed Dispersal. Ann Rev Ecol Syst 13: 201-228.

Hughes L, Dunlop M, French K, Leishman MR, Rice B, Rodgerson L AND Westoby M. 1994. Predecting dispersal spectra: a minimal set of hypotheses based on plant attributes. J Ecol 82: 933-950.

IANNUZZI R. 2002. Afloramento Bainha (Criciúma), SCFlora Glossopteris do Permiano Inferior. In: SCHOBBENHAUS C, CAMPO DA, QUEIROZ ET, WINGE $M$ and BEBERT-BORN MLC (Eds), Sítios Geológicos e Paleontológicos do Brasil, Brasília: DNPM/ CPRM - Comissão Brasileira de Sítios Geológicos e Paleobiológicos (SIGEP) 1: 23-31.

IANNUZZI R, MARQUES-TOIGO M, SCHERER CMS, CARAVACA G, Vieira CEL and Pereira LS. 2003. Phytobiostratigraphical revaluation of the southern Brazilian Gondwana sequence (Paraná Basin, Lower Permian). In: INTERNATIONAL CONGRESS ON CARBONIFEROUS AS PERMIAN STRATIGRAFY, Abstracts, Utrecht, Netherlands 15: 240-242.

IANNUZZI R, SCHERER CMS AND CARAVACA G. 2007. Taphonomy and paleoecology of the southern Brazilian Glossopteris Flora (Paraná Basin, Lower Permian). In: DIAZ- MARTINEZ E AND RÁBANO I (Eds), $4^{\text {th }}$ European Meeting on the Palaentology ans Stratigraphy of Latin America Cuadernos del Museo Geominero, Madrid, España 8: 201-206. 
IANNUZZI R ET AL. 2006. Afloramento Morro do Papaléo, Mariana Pimentel, RS - Registro ímpar da sucessão sedimentar e florística pós-glacial do Paleozóico da Bacia do Paraná. In: WINGE M, SCHOBBENHAUS C, BEBERT-BORN MLC, QUEIROZ ET, CAMPOS DA, SOUZA CRG and FERNANDES ACS (Eds), Sítios Geológicos e Paleontológicos do Brasil, Brasília: DNPM/ CPRM - Comissão Brasileira de Sítios Geológicos e Paleobiológicos (SIGEP). Disponível em http://www.unb. br/ig/sigep/sitio101/sitio101.pdf.

IANNuZzi R, SOUZA PA, Scherer CMS AND Holz M. 2008. Plantas Fósseis na ioestratigrafia dos Depósitos Permianos do Rio Grande do Sul. In: IANNUZZI R and FRANTZ JC (Eds), 50 Anos de Geologia, Porto alegre: Ed. Comunicação e Identidade, p. 265-281.

JAKOBSSON A AND ERIKSSON O. 2000. A comparative study of seed number, seed size, seedling size and recruitment in grassland plants. Oikos 88: 494-502.

Leguizamon RR. 1971. Paleophytologia Kurtziana III. 6. Revision de las semillas platispermicas de Bajo de Los Velez (San Luis), ilustradas en el "Atlas de Plantas Fosiles de La Republica Argentina" (F. Kurtz, 1921). Ameghiniana 8(3/4): 259-264.

Leishman MR, Whight IJ, Moles AT And Westoby M. 2000. The evolutionary ecology of seed size. In: FENNER $M$ (Ed), Seeds: the ecology of regeneration in plant communities, $2^{\text {nd }}$ ed., Wallingford, UK: CABI Publishing, p. 31-57.

LORTS CM, BRIGGERMAN T AND SANG T. 2008. Evolution of fruits types and seed dispersal: a phylogenetic and ecological snapshot. J Syst Evol 46(3): 396-404.

MARTIN RE. 1999. Taphonomy: a process approach. Cambridge Paleobiology Series, v.4. Cambridge University Press, $524 \mathrm{p}$.

Modesto SP. 2006. The cranial skeleton of the Early Permian aquatic reptile Mesosaurus tenuidens: implications for relationships and palaeobiology. Zoo J Linn Soc 146: 345-368.

Moles AT, Ackerly DD, WebB OC, Tweddle JC, Dickie JB AND WESTOBY M. 2005. A brief history of seed size. Science 307: 576-580.

OLIVEIRA MECB AND PONTES CES. 1976. Algumas observações sobre cordaitófitas da Formação Rio Bonito. Grupo Tubarão Bacia do Paraná Brasil. In: CONGRESSO GEOLÓGICO CHILENO, 1. Actas, Santiago do Chile 3: L22-L81.
Paim PSG, Picolli AEM, SATURi JAD, Munaro P, Holz M AND GRANITOFF W. 1983. In: SIMPÓSIO SULBRASILEIRO DE GEOLOGIA, 1. ATAS, Porto Alegre, p. $142-159$.

REMY W. 1975. The floral changes at the Carboniferous-Perminan boundary in Europe and North America. In: BARLOW JA (Ed), The Age of the Dunkard, Morgantown: West Virginia Geological and Economic Survey, p. 305-355.

Richter M. 2000. Peixes fósseis do Rio Grande do Sul. In: HOLZ M and DE ROS LF (Eds), Paleontologia do Rio Grande do Sul, Porto Alegre: CIGO/UFRGS, p. 162-175.

SCOTT A AND COLLINSON M. 1983. Investigating on fossil plant beds, part 1: the origin of fossil plants and their sediments. Geology Teaching 7(4): 114-122.

SOUZA JM AND IANNUZZI R. 2007. The genus Cordaicarpus Geinitz in the Lower Permian of the Paraná Basin, Rio Grande do Sul, Brazil. Rev Bras Paleontol 2: 95-106.

Souza JM AND IANNuZzi R. 2009. Sementes do gênero Samarapsis Goeppert no Permiano Inferior da Bacia do Paraná, Sul do Brasil. Rev Bras Paleontol 12(1): 5 - 16.

SPICER RA. 1991. Plant taphonomic processes. In: ALLISON PA AND BRIGSS DE (Eds), Taphonomy: releasing the data locked in the fossil record. Topics in Geobiology, v.9. New York: Plenum Press, p. 71-113.

TAYLOR TNAND TAYLOR EL. 1993. The Biology and Evolution of Fossil Plants. $1^{\text {st }}$ ed., Nova Jersey, Prentice Hall, 982 p.

TIFFNEY BH. 1984. Seed size, dispersal syndromes and the rise of the angiosperms: evidence and hypothesis. Ann Mo Bot Gard 71: 551-576.

TIFFNEY BH. 1986. Evolution of seed dispersal syndromes according to the fossil record. In: MURRAY DR (Ed), Seed dispersal. San Diego: Academic Press, 322 p.

TIFFNEY BH. 2004. Vertebrale dispersal of seed plants through time. Annu Rev Ecol Evol Syst 35: 1-29.

VAN DER PJIL L. 1969. Principles of dispersal in Higher plants. Springer-Verlag, New York, $153 \mathrm{p}$.

WANG BC AND SMITH TB. 2002. Closing the seed dispersal loop. Trends Ecol Evol 17(8): 379-385.

Willson MF AND TRAVESET A. 2000. The ecology of seed dispersal. In: FENNER M (Ed), Seeds: the ecology of regeneration in plant communities. $2^{\text {nd }}$ ed., p. $85-110$. 